Analiza i Egzystencja 49 (2020)

ISSN 1734-9923

DOI: $10.18276 /$ aie.2020.49-04

\title{
TOWARDS A POOR PHENOMENOLOGY. ON CERTAIN STRUCTURAL SIMILARITIES BETWEEN PHENOMENOLOGY AND JERZY GROTOWSKI'S PHILOSOPHY OF THEATER ${ }^{1}$
}

Keywords: phenomenology, phenomenological movement, philosophy of theater, Jerzy Grotowski, performans, philosophy of body.

\section{Introduction}

Since its rise, phenomenology has been developing in parallel in two basic areas which complement and permeate each other. On the one hand, there is

* Daniel Roland Sobota - PhD, Professor at the Institute of Philosophy and Sociology at the Polish Academy of Sciences. A graduate of the Nicolaus Copernicus University of Toruń. Research interests: metaphysics, German philosophy of the nineteenth and twentieth centuries, especially Martin Heidegger's philosophy and early phenomenology, philosophy of question, philosophy of theater and philosophy of sport. An author of monographs: Sources and Inspirations of Heidegger's question of Being (vol. 1-2, Bydgoszcz 2012-2013) and A Birth of Phenomenology from the Spirit of Question: Johannes Daubert and the Start of the Phenomenological Movement (Warszawa 2017) and An Essay in the Philosophy of History (Warszawa 2018).

Address for correspondence: Polish Academy of Science, Nowy Świat 72, 00-330 Warszawa, Poland. E-mail: dsobota@ifispan.waw.pl.

${ }^{1}$ The research was funded by Narodowe Centrum Nauki (the National Science Center) in Poland as a part of the grant receivable due to being awarded a scientific degree of $\mathrm{PhD}$ from DEC-2015/16/S/HS1/00257. 
a direction that Edmund Husserl assigned to it, particularly in his published books. He reduced phenomenology to a theory of knowledge, apophantic analytics, analysis of cognitive acts, justification of pure logic, the building theory of the subject, a theory of science and so on. Phenomenology is thus conceived of as a theory of cognition (Płotka, 2015). On the other hand, we have the phenomenology that derived from the perspective determined by Alexander Pfänder and Max Scheler. In their works, phenomenological research focuses on the emotional and affectional life, on the psychological character, will, on values, social life and ethics. One can venture a statement that without Husserl's works phenomenology would be blind, without Pfänder and Scheler it would be empty. Without this ambitious, and thought of as a task to future generations, Husserlian project of phenomenology regarded as a fundamental and primordial science, Pfänder's and Scheler's research would constitute a "merely" interesting proposal of certain determinations within the so-called regional ontology. Without Pfänder's and Scheler's works Husserl's phenomenology would remain a grand theoretical framework of a great philosopher-mathematician, the framework more and more moving away from living reality towards pure transcendental structures. Certainly, this juxtaposition becomes problematic once we take into account what Husserl's manuscripts actually contain. But even when late Husserl deals with the problematics of life-world (Lebenswelt) and of history, he still does so in the spirit of "scientific reasoning", which only the phenomenologist such as Heidegger, Sartre or Levinas tried to dissociate themselves from. All in all, from the beginning between these two orientations a lively dialogue took place and led to the fact that what at the beginning of the phenomenological movement proceeded separately, in the course of implementation of what was phenomenological had to eventually converge. In the following decades of the development of phenomenology the work on the transcendental justification of all knowledge went beyond the boundaries of pure consciousness and entered the area of the living bodiliness, the world of environment and intersubjectivity. The history of the phenomenological circle is a return to the world, to life, to others, to acting...

This act of bringing of phenomenology down from heaven to earth is clearly evidenced by the post-war history of French phenomenological movement (Waldenfels, 1983). Phenomenology is said to have experienced a few turns: an existential, hermeneutic, aesthetic and a theological one. Increasingly frequently, one is looking for opportunities to do phenomenology 
as "concrete practice". In this spirit, in the last decade the phenomenological motto of "back to things" is adhered to by e.g. Natalie Depraz. As she says, "the epistemology is in fact inseparable from the practice in which we engage. [...] To cognize is to find out how to act on the reality in a particular real situation" (Depraz, 2010, pp. 17-18). Depraz speaks of the attitude of a phenomenologist-practitioner, as well as of phenomenology in action, in which phenomenology, not having anything of its own, still allows for something that cannot be subsumed under the label of phenomenology as such to enter its own territory. This is the original unfolding of the idea of phenomenology as xenology (Waldenfels, 2002, chapt. 4).

Presenting its own "applied phenomenology", Depraz distinguishes seven different contexts in which there occur experiences that are congruent with phenomenology and add to the richness thereof. Some of them are areas of internal experience that manifest themselves in scientific practice as well as spiritual ones. They serve as "paradigms of practical experience of phenomenology" (Depraz, 2010, pp. 87-88). These include: neurophenomenology, Eastern orthodox theology, Buddhist meditation. Besides that, Depraz distinguishes the experience in relation to Other. She mentions the psychiatrically-therapeutic practice, ethno-methodological anthropology and psychology of mimesis in children. At the end, she switches to first-person psychology of aesthetic experience, associated primarily with her own practice of philosophical writing. Phenomenologically speaking, all these domains are mutually consistent. This consistency has four fundamental characteristics that can be particularly refreshing from the point of view of different phenomenology: 1 . The phenomenological knowledge is acquired always in the first person, and the determining factor is a compassion; 2. "practical foundation determines the ontological grounds of conduct", ontology here is always practical; 3 . bodily experience is placed in the center of research; 4. a special descriptive language is required (Depraz, 2010, p. 113).

These assumptions that make up what Depraz called different phenomenology and applied phenomenology, and which can also be described as pragmatic or performative phenomenology too, we found in a completely different field of cultural activities. It is the theatrical works (performances and writings) by Jerzy Grotowski. The most important, while not the only one, goal of this paper is a presentation of Grotowski's philosophy of theater in the context of the most important discoveries of phenomenology. We leave 
it as an open question whether Grotowski's work can be subsumed under phenomenology. However, it seems that his discoveries in the field of anthropology of theater not only have much to offer to the latest phenomenology, which combines the experience of corporeality and intersubjectivity with the space of aesthetic and religious experiences, but also anticipates many of its ideas. A further aim of this article is an introduction of Grotowski's ideas into the philosophy. So far Grotowski has remained an actually unknown figure within the purview of professional philosophy. It is a regrettable fact because in his work he made many discoveries which run parallel to or anticipate what has happened and is still happening in modern philosophy. Just to mention that Grotowski is one of the initiators of the so-called performative turn in the humanities. One of the reasons that Grotowski is unknown in the twentieth-century philosophy is a fact that he placed his thought in the philosophical context which is nowadays of little importance (e.g. neognosis) (Osiński, 2009, pp. 177-225). And the commentators who followed Grotowski's work proceeded precisely along these lines. We want to place Grotowski's work near phenomenology, i.e. in the space in which it has never been placed before. ${ }^{2}$

In the history of European culture, the combination of philosophy and theater is nothing new. We mean the philosophy of Friedrich Nietzsche and his interpretation of the birth and collapse of Greek tragedy (Nietzsche, 1905). According to Nietzsche, Attic tragedy comes to an end when a theoretical man came into the historical scene; the theory is an opposition of theater. This statement is possible and justifiable because both phenomena share a common foundation. It is the meaning of the Greek word $\theta \varepsilon \omega \rho \varepsilon i$, which is connected with both $\theta \varepsilon \dot{\alpha} \alpha \rho o v$ and $\theta \varepsilon \omega \rho i \alpha$. The theater and theory are derived from a common activity of watching. Greek $\theta \varepsilon \omega \rho \varepsilon$ ív means first "to watch". With

${ }^{2}$ Although Kris Salata in his book The Unwritten Grotowski: Theory and Practice of the Encounter (Salata, 2012), which can be justifiably described as the most philosophical attempt to interpret Grotowski's output so far, refers to the latter as the phenomenology of being, the book still lacks any references whatsoever to the works of representatives of the phenomenological movement (it is only several times that the name of Heidegger is mentioned) or to the issues raised by them. Since Salata does not explain what he understands by the concept of phenomenology, based upon the content of his book one can reasonably infer that he uses the word "phenomenology" rather loosely, with his understanding of the word and the one adhered to within the so-called phenomenological movement being poles apart. 
reference to this meaning, the attitude of the philosopher was designated as

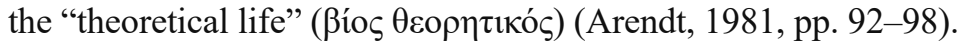

Indeed, $\theta \varepsilon \omega \rho$ í $\alpha$ is "watching", but not only in the sense of the passively observing from the distance, reflecting on, meditating, but also "actively" participating in the ceremony, in the pageant, procession, pilgrimage, participation in the festival. When Nietzsche conceives of tragedy and poetry as watching, it refers to the "active" meaning of "theory". $\theta \varepsilon \omega \rho i ́ \alpha$ itself is a celebration in which, as noted by Pythagoras (Laertius, 2013, sec. 1.12, 8.8; Gajda, 1996, pp. 27-29) $)^{3}$ in his definition of philosophy, you can participate in different ways: as an actor, trader or spectator. Being a spectator is therefore only one of the ways of participating in the "theory". Another one is to be an actor (Gadamer, 2004, pp. 121-122).

But this is only one side of the affinity between theater and philosophy. Another form is Francis Bacon's idola theatri. Bacon described them as "idols which have immigrated into men's minds from the various dogmas of philosophies, and also from wrong laws of demonstration" (Bacon, 1905, book I, aphor. 44).

It turns out that theater and philosophy combine both the search for the truth and art of creating a simulacrum. The problem is to separate one from the other. This is an important moment which is a starting point of Husserl's phenomenology and Grotowski's work. In the forthcoming part of the text, while speaking of phenomenology and its problems, I shall avail myself of various works by the recognized representatives of the phenomenological movement (Spiegelberg, 1960). However, the majority of references I shall make to the works of Husserl, who is responsible for the introduction of and the most comprehensive elaboration on the new sense of the concept of phenomenology. At this point, the works subsumable under the domain of the phenomenology of theater are of no interest to me (States, 1985; Johnston, 2017). Instead, what I take interest in are the structural similarities between the two spiritual and cultural formations which are phenomenology and Grotowski's theater. Before I embark on comparing Grotowski's philosophy of theater and the standpoint of phenomenology, I shall briefly present the earliest works of the director of Apocalypsis cum figuris because they are virtually unknown among philosophers.

\footnotetext{
${ }^{3}$ Also Plato was apologetic of understanding philosophy as a misterium, which reminds us of his inclinations towards Orphic thought.
} 


\section{Jerzy Grotowski's Philosophy of Theater}

Nietzsche's ideas are one of the most important philosophical premises of Jerzy Grotowski's work. In the next part of this text we want to focus on the first period of Grotowski's work, i.e. Theater of Performance (Osiński, 1980). Without doubt, the subsequent periods of development of Grotowski's work, and perhaps especially these ones, have much to offer to philosophy and phenomenology. However, the fact that because Grotowski forged his philosophy of theater while arranging performances confines our presentation to the first period of Grotowski's work. We do not intend to discuss his concrete performances. The subject of our interest are the texts which Grotowski published at that time. The most important of them are texts collected in the book Towards a Poor Theater (1968) (Grotowski, 1984).

Nietzsche's philosophy is one of the most important philosophical assumptions of Grotowski's work. ${ }^{4}$ And this does not exclusively apply to the early work of the German philosopher. Grotowski's point of departure is Nietzsche's diagnosis of contemporary culture: "Death of the gods puts a man in the desert. [...] And nothing protects us from the terror of death" (Grotowski, 2012, p. 122). ${ }^{5}$ Perhaps only art is able to develop human "major, metaphysical desire" of infinitude. It is about understanding and affirmation of life and the "weight and bitter fate", it is about producing in man "nonreligious source of being joyful, a source of peace, liberating man from the terror of death" (p. 131). In the past - before the age of theoretical man - this role was played by the theater which was not separated from

\footnotetext{
${ }^{4}$ Certainly, there are more strictly philosophical inspirations in Grotowski's works. In this context, one normally enumerates - next to already-mentioned Nietzsche Eastern philosophy, gnosis, Christian mysticism, Freud's psychoanalysis and Jung's depth psychology. It is worth mentioning that in parallel to his first theatrical attempts, on the turn of 1957, Grotowski was conducting a series of open lectures lasting a few weeks, the lectures being dedicated to Eastern philosophy. See also: Kalendarium życia i działalności twórczej Jerzego Grotowskiego, available at: www.grotowski.net/ narzedziownia/kalendaria/jerzy-grotowski (2.10.2019).

${ }^{5}$ In the forthcoming parts of the paper, the numbers of pages from the above-mentioned edition will be indicated in brackets in the body of the text, right after a given quoted passage. Only the longer fragments of Grotowski's utterances are quoted for English publication (Grotowski, 1984).
} 
religion, politics and wisdom. Can you now "return"to this function of the theater and make it the center of the earthly man's salvation?

Certainly, it cannot be achieved by the conventional theater which focuses on the imitation of bourgeois "everyday life". This theater - according to Grotowski - is already dead. When competing with a cinema or television, the theater lost to both of the former. If in the face of "the agony of fideism", the theater should exploit human "search for hope", this "surplus imagination and anxiety", previously taken advantage of by religious rituals, it must be a new theater: "neo-theater" (p. 137). Theater as a "philosophical mystery" (p. 140), the theater that has "philosophical ambitions" (p. 144).

Trying to answer the question "What is the essence of theater?" (p. 191), Grotowski had come a long way which made him in the first period of his work come up with the idea of "poor theater". His research focused on the search for "the absolute of theatricality" or "the gist of theatricality". According to Grotowski, theater is a unique art. It is in fact a place of a direct, living encounter and dialogue of people - artists and spectators - which gives rise to a common immersion "in the problems of relationship between people and between man and the cosmos, in order to derive therefrom, as from legendary Colchis, a seed of hope" (p. 124). The theater is therefore of therapeutic nature (p. 181). It is a panacea for the crisis of contemporary culture. In 1958 young Grotowski noted:

Difficult and often tragic experiences of the twentieth century have created the need for the theater, which - without lying and running away from problems, even drastic ones - gives man hope, ethical and social awareness, and restores the meaning of existence (p. 95).

This early Grotowski's pronouncement already perfectly reflects what constitutes a "grain of truth" throughout his work. Contrary to what is commonsensically associated with the words "theatrics" and "theater", which usually means pretending, lying, creating the illusion, putting on a mask, game, play, convince, etc., what Grotowski demands from the theater is "not lying". It's about the absolute truth, absolute sincerity, which, restoring the meaning of existence, gives man hope. For what? That it overcomes "the problem of human loneliness, the inevitable human evanescence".

Calling the theater an encounter and dialogue between the actors and the audience, Grotowski did not go beyond mainstream ideas on the art of theater yet. What was still lacking is some purificatory conceptual work and 
drawing consequences of utmost importance. In his programmatic writing Towards a Poor Theater (1965) and in many interviews given at the same time Grotowski was trying to arrive at the idea of the theater by excluding what is not theater (via negativa). The richness of theater, however, lies not in the technical means of creating illusion on the stage, the illusion being supposed to faithfully mimic reality, but - paradoxically - lies in its poverty, i.e. in discarding everything what is outside. To get to the gist of theatricality takes two groups of people meeting in the empty space: the actors and the spectators. That is all.

The acceptance of poverty in theater, stripped of all that is not essential to it, revealed to us not only the backbone of the medium, but also the deep riches which lie in the very nature of the art-form.

(English p. 21; Polish p. 251)

This is it - the meeting of actors and spectators does not happen spontaneously, but must be prepared in the smallest detail earlier (the theater is not a happening). Grotowski relies on craftsmanship, appreciates work ethic, in which profession is combined with one's calling. To reach the essence of theater, and for the theater to become what it is, you need genuine craftsmanship, the principles of which - according to Grotowski - are yet to be developed. "The actor is a creator who shapes the work of art in his own body" (p. 287). Grotowski develops complex techniques and exercises on body, bodily movements and voice, which are aimed at causing the theater to emerge. The physical training does not therefore amount to learning, but to unlearning (pp. 282, 315) - unlearning some clichés, habits (mental and physical) that hinder the disclosure of the spiritual process. The technique should serve to disarm and not to arm. Hence, there is no method or system by Grotowski, which could be used as a recipe for a "good performance". "Each technique leads to metaphysics" (p. 248) - repeats Grotowski. What is the result of this training? When the actor - after many months, and even years of work, centered around his person (body and soul), in contact with a partner - achieves in the presence of and vis-a-vis (but not: for) spectators,

${ }^{6}$ In this respect, Grotowski highly appreciates the works of his predecessors, especially the ones by K. Stanislavsky; at the same time, Grotowski maintains that the achievements of the grand reform of theater at the turn of the previous century were not fully developed or refined. 
the so-called total act. Then spectators become witnesses. According to Grotowski, by participating in this act all people experience the metaphysical unity. In this way, the theater comes back to its ancient roots, in which there was no division between art, philosophy and religion. It is a kind of secular ritual, secular liturgy through which man's inherent metaphysical need is temporarily satisfied.

The total act is the most important concept in Grotowski's early philosophy of theater. About this, what this act consists in, says Grotowski repeatedly using the religious parlance:

Here everything is concentrated on the "ripening" of the actor which is expressed by a tension towards the extreme, by a complete stripping down, by the laying bare of one's own intimity - all this without the least trace of egotism or self-enjoyment. The actor makes a total gift of himself. This is a technique of »trance « and of the integration of all the actor's psychic and bodily powers which emerge from the most intimate layers of his being and his instinct, springing forth in a sort of "translumination".

[...] The education of an actor in our theater is not a matter of teaching him something; we attempt to eliminate his organism's resistance to this psychic process. The result is freedom from the time-lapse between inner impulse and outer reaction in such a way that the impulse is already an outer reaction. Impulse and action are concurrent: the body vanishes, burns, and the spectator sees only a series of visible impulses.

[...] The requisite state of mind is a passive readiness to realize an active role, a state in which one does not "want to do that" but rather "resigns from not doing it".

(English pp. 16-17; Polish p. 246)

One must afford extreme honesty with oneself and with the audiencewitnesses, the maximum sincerity. The actor must train his body so that it does not hamper the possibility of disclosing deep inner spiritual experiences which come mostly from the past and are associated with important events in human life (boundary situations). The art of the actor is retrieving the access to the intimate memories and associations (not: emotions), or rather to access anew what has then happened (in the physical sense) - it is because the "memories are always physical reactions" (p. 268) and "the body is the memory" (p. 388) - and by dint of bodily signs constructed on the basis 
thereof (not: invented) and ordered in the smallest details - revealing it to others. So, this is an act of confession, redemption, self-sacrificing, love. It is like a journey to your own life to which others are invited. The theater is a vehicle (p. 350). It is a true theater of cruelty (p. 360), "a sacred theater" (Brook, 2007, pp. 12-13). ${ }^{7}$

Creating works of art consists then in preparing the conditions of the possibility of disclosing the truth, so that man realizes his struggle for fulfillment, for living authentically, and for wholeness. Through total act man departs from the logic of everyday life, from its incompleteness and devotes himself to the paradoxical and dialectical logic of life. The material of creation is his own life, which contains the truth about "his/her man" (Theophilus of Antioch). The theater reveals "that there is man", "fact of life" (pp. 431-432).

This fact of life is an objective one. By reaching the most intimate experiences in his life, by unblocking the body and finding signs that comprehensibly reveal the truth of life, an actor transcends his own "self" towards what is common to him, society and nature:

In moments of fullness what is animalistic in us, is not only animalistic, but rather it embraces the whole nature. Not human nature, but - the whole nature in man. What is then simultaneously actualized is a legacy of social man, man as homo sapiens. But this is not a duality. It is the unity of man. And then it is not "I" that does the act, "my man" realizes act. At the same time me and genus humanus. The whole human context: and social development, and everyone else - inscribed in me, in my memory, in my thoughts, in my experience, in my breeding, in my form, in my potential.

(only in Polish publication, p. 475)

In the body-memory there are certain archetypes that "bind us to the past". ${ }^{8}$ Archetype "is the symbolic form of knowledge of man about himself or - if you prefer - of ignorance" (p. 212). In the archaic theater "viewers

${ }^{7}$ The idea of the restauration of theater as a ritual and "sacred" phenomenon, which, while demanding maximal honesty, unites the actor with spectator and both of them with cosmos. Grotowski owes as much to Nietzsche as to Antonin Artaud. On the relations between festivity and glee derived from the infliction of pain, see: Nietzsche (1905-1906, p. 69).

${ }^{8}$ On this occasion, Grotowski recalls Jung; however, he admits that he uses the word 'archetype' "without Jung's philosophical connotations" (p. 212). 
saw the new personal truth in the truth of the myth, and through the element of horror the viewer ultimately reached the climax, that is catharsis" (p. 252). The total act is also a historical one. "Of course, our life is individual and personal; we live in the present, but we are the result of something bigger - the history more extensive than our personal one [...]" (p. 376). "We are like a big book in which what is inscribed is the presence of other human beings" (p. 503). The total act fuses a deep history of human being with actor's history. Expression leads to objectification. It takes place by clear signs-gestures: "a spiritual process, not accompanied by a formal articulation, discipline, or the structuralization of a role collides with formlessness" (p. 247). The difficulty lies in the combination of spontaneity and discipline.

One of the most important signs is a voice. It is "an extension of our body" (p. 416). "The act of total self-revelation is complete at the time of the extreme sincerity. When this happens, there is a place for words. At this point, words are inevitable; what then arises is a translanguage, whose base is derived from the biological and the physical" (p. 377). Spoken and sung words correspond to the content of the text which was chosen as the basis for the play. Grotowski chose texts recognized as classical (Kain by Byron, Faust by Goethe, Dziady by Mickiewicz, The Tragical History of the Life and Death of Doctor Faustus by Marlowe, texts in Sanskrit, Kordian by Słowacki, Akropolis by Wyspiański, Biblical texts and others) (Osiński, 1972, pp. 347-351; Degler, Ziółkowski, 2006). They allowed "to go out to encounter our own sources" and to look for something that would be "like a crystal of challenge, something elementary, like the experience of our ancestors, like the experience of others, like the voice of the abyss" (p. 365), and even "the voice of the dead". Each of the texts presents in a literary form some archetype, which in the space of the theater should be reconstructed and revealed at the level of the body. The basic principle of hermeneutics which applies here posits that a universal truth about man's destiny is revealed and has a chance to become alive in the contemporary consciousness even as it gets immersed in "the human body, breath and internal impulses". It is an "incarnation of the myth". Because today, "collectivity is no longer defined by religion and traditional forms of myth are in a state of »grinding «" (p. 252), because there is "no one faith" and contemporary culture and the individual self is like the tower of Babel (Ludwik Flaszen, p. 362); so, instead of the identification with the myth what remains is a confrontation - "between beliefs and life experience of past generations 
and our own experiences and prejudices" (p. 326). Theater as a gathering of people in the context of the tradition is possible today only through collision, struggle and testing different meanings. The central battleground is even the human body:

[...] even with the loss of a »common sky« of belief and the loss of impregnable boundaries, the perceptivity of the human organism remains. Only myth - incarnated in the fact of the actor, in his living organism - can function as a taboo. The violation of the living organism, the exposure carried to outrageous excess, returns us to a concrete mythical situation, an experience of common human truth.

(English p. 23; Polish p. 252)

Therefore, the content of the performance is always a myth, which is desecrated, but due to that, one affirms the past. Tadeusz Kudliński referred to this phenomenon by the formula, oftentimes repeated by Grotowski, "dialectic of ridicule and apotheosis" (p. 213 et seq.) (Degler, Ziółkowski, 2006, pp. 139-140). This very formula reflects the profound irony contained in the performances of Grotowski. From the early performances Grotowski realized this approach to theater, which, not resigning from demonstrating the tragic truth concerning the whole of existence, introduces an element of fun, humor and playing with a convention. This is a true "theater of Dionysus", which takes place "between the two extremes of reality: the tragic and grotesque" (p. 160). In remarks to an early performance that he made on the basis of Siakuntala by Kalidas (1960) Grotowski spoke about modern theater as a realization of the myth of the dancing Shiva. Theater is "playing Shiva", the dance of the whole being.

The implementation and inevitable modification of the above-described artistic assumptions, lasting for the next decade, placed Grotowski outside the theater. "We should abandon the concept of ritual theater, because it is not possible nowadays, and this is due to the lack of commonly held beliefs" (p. 362). Other Grotowski's statements from the end of the sixties do not leave any doubt as to his assessment of the possibilities of theater: "I doubt the possibility of direct participation in today's theater, in an era where there is neither common faith nor a liturgy rooted in the collective psyche as the axis for the ritual" (p. 447). "I think you have to treat theater as an already abandoned house, something unnecessary, which is not really indispensable" 
(pp. 469-470). "I do not feel that for me the theater was the target. There is only Act" (p. 478). "I do not love theater" (p. 523).

\section{Towards a Poor Phenomenology}

At first glance, it seems that Grotowski's philosophy of theater has little in common with phenomenology. In the second part of this article we will try to show that it is quite the opposite. We want to show that in fact there are a lot of similarities between Grotowski's philosophy of theater and phenomenology. Maybe this analogy contains a more deeply rooted common basis for our benchmark, the benchmark constituting a source element, an origin and a root of all high spiritual activities.

The interest in the phenomenon of theater in the context of early phenomenology research has already have a certain tradition. It is enough to recall Edmund Husserl's analyses. Published in 1980 volume XXIII of Husserliana entitled Phantasie, Bildbewusstsein, Erinnerung includes Husserl's description, probably from 1918, which he devoted to the perception of the theatrical performance. The analysis requires a distinction between several types of imagination (Husserl, 1980, p. 514). We only mention it in passing here. One could, of course, try to apply Husserl's analyses to the theater, as conceived of by Grotowski. It would yield - I think - a lot of useful discoveries. It is a fact that Husserl's analyses are conducted from the perspective of the viewer and relate to the theater in its traditional nineteenth-century form. One can ask how much the revolution in theater entails inevitably a change in the way it is received. New thinking about the theater takes into account not only what is happening in the space of the "stage", but also what happens to the viewers. Our task, however, is not to correct Husserl's "theater philosophy" in the context of Grotowski's activity. Instead, we shall compare the above-stated Grotowski's philosophy of theater with some of the main ideas of phenomenology which form the common assumptions and thinking of the phenomenological movement.

\section{Der Gott ist tot}

In his succinct programmatic work Philosophie als strenge Wissenschaft, Husserl mentions the misery of the time and life that results from the 
overturning of all previous values, which have been so far of utmost importance to humanity. Despite this fact, the metaphysical need for the infinite and absolute is still alive in man. But how to satisfy this need? How to continue to be a man in miserable times? Nietzsche meant the situation of life in the era of the "death of God". The motto Gott ist tot does not only mean - as you know - the collapse of traditional religious beliefs, but it penetrates much deeper. It is about the decline of the belief in such a metaphysical interpretation of reality which claims that at the core of all reality there is an ever-lasting Substance, be it the eternal Being, God, etc. (Heidegger, 1997, pp. 171-216). This supposition turned out to be a mere appearance. The reality is a phenomenon at the basis of which there is nothing; or, strictly speaking, there is Nothingness. The reality is therefore only a game of appearances and shadows, a space of aesthetic experience and artistic creativity. As Marx said, "everything solid melts into air". The turn of the century was the era of fin de siècle. Human life became an issue.

Those cultural circumstances bred phenomenology. If the latter is to provide a remedy to the crisis, phenomenology must have maximalist goals. It is an exact science that discovers absolute truth. How can this be done, however, if the reality is just a make-believe and a phenomenon? As Nietzsche says, if there is no truth beyond a phenomenon, the phenomenon itself is truth. The answer to the crisis of culture cannot rely on insisting on ascertaining some truth lying beyond the phenomenon. Transcendence is a fiction. What remains then is the domain of immanence. How can then something which is apparently absolutely true be identified with what is merely phenomenal?

The metaphysical principle underlying phenomenology seems to coincide with Nietzsche's diagnosis of the exhaustion of resources of transcendent truth. The principle says: there is Being only insofar as there is a Phenomenon. Husserl expressed the same truth saying: "In the mental sphere there is no difference between phenomenon and being" (Husserl, 1910-1911, p. 312; Henry, 2007, p. 112). This does not mean that when we narrow down our analysis to sheer phenomena, what remains is only a fragmentary description of ever-changing reality. In the phenomenon Husserl perceives a possibility of reaching the essence thereof, the essence being possibly cognizable apodictically. The essence is not the same as reality. It is only the internal possibility of things. The domain of phenomenology is a possibility (Heidegger, 1987, p. 63), and its "vital element" is a fantasy 
(Husserl, 1976, §70). One could therefore say that the way to truth runs through appearance. However - in Husserl's opinion - only in this way you can establish objective and solid values and eo ipso save European man.

Grotowski perceives the issue very much alike. But his remedy for crisis is not science understood as a description of the essence of the phenomenon, but rather art and theater. In this respect, he definitely remains closer to Nietzsche than to Husserl. However, the reasoning of three of them is very similar indeed.

In the world of phenomena everything becomes a game and theater. It is the reason why the metaphor of the world as a theater made a career in the twentieth century. It is the reason why in the twentieth century the concept of game became so popular, even in serious philosophy (L. Wittgenstein, H.-G. Gadamer, E. Fink). Theater is the domain of delusion, lying, deception and simulation. Grotowski points out that in ancient times the art of acting was not highly esteemed, and those who occupied themselves therewith lived on the margins of society. As Husserl said in his analyses, on stage everything happens "as if". This is the domain of imagination and unreality. So how is it possible in this world of appearance to reach such a thing as truth? The possibility of the access thereto sparks - according to Grotowski - the reflection on the essence - the essence of theater. He asks: what is theater in its deepest essence? And by virtue of this question, combined with theatrical practice, Grotowski opens up a new perspective of the search for truth in the phenomenon.

\section{Zu den Sachen selbst!}

The less reality, the greater the longing for things. One cannot just talk about the truth. Actually, one must do it even if it is only an act of reflection. In his phenomenological manifesto Husserl says: "Away with empty word analyses! We must question the things themselves. Back to experience, to seeing, which alone can give our words sense and rational justification!" (Husserl, 1910-1911, p. 305). This commonly known slogan of phenomenology is its hallmark: the extreme objectivist attitude. At the beginning of the twentieth century it lured to phenomenology so many young and talented people. For example, Wilhelm Schapp talked about devotion of things: "Die erste Voraussetzung ist eine unbedingt Hingabe, Vertiefen ein in die Sachen selbst; nicht ein Reflektieren über die »Sachen«, sondern ein aufnehmen, Auskosten 
der »Sachen«; Sache hier im Sinne weitesten genommen" (Schapp, 1976, p. 13). Conrad-Martius spoke about himself that she is "obsessed with things" (Sachbessesen). Let things themselves speak, and only them - this is the longing of every phenomenologist.

This imperative, which is at the basis of phenomenology, can be also easily found at the root of Grotowski's philosophy. You can read Husserl's motto in the context of Grotowski's philosophy almost literally. So, away with empty words! And that means: away with the theater as a field of empty words! Hamlet's "words, words, words" - isn't it the way that theater has defined itself for centuries? The art of words and theater were always inextricably intertwined. The actor is the one who primarily speaks on stage to the audience. Auditorium - a place where you listen. It is the phenomenon of the rich theater: to enchant the audience with words, to express "the world" and to express grand ideas that humanity bred with a variety of gestures. Far from it, when we sit in a theater and open our eyes, we see that the original theatrical phenomenon is reducible to a particular living man appearing on the scene. Here is a primary phenomenon and material of theater. No words are yet pronounced when an actor appears. The theater is not a play and neither is it a literary genre. Grotowski refrained from calling himself a "philosopher". He thought that he does not create any philosophy or a theory ("words, words, words"). He was a practitioner. Everything he said related to practice, it was a description of the practice - always imperfect and secondary. What matters is a living concrete, physical person who acts on stage. A man is alpha and omega of theatrical reality. No unnecessary words, big ideas and pompous gestures. Hence the name of Grotowski's theater: the laboratory. It was supposed to serve as a reminder that it is all about a tedious work with things, a "scientific" devotion to things. And not speculation or invention.

\section{Gemeinschaft}

Although Husserl himself was doing his phenomenology along the lines of lonely ego - and monological reflection, which reminds us of Descartes's investigations, he thought the gradual immersion in the abyss of transcendental subjectivity is the work supposed to be continued by future generations. He perceived in it a genuine community fighting for a cause and taking responsibility for the fate of humanity. What constitutes the essence 
of phenomenology is the fact that it allows for the pluralism of approaches and perspectives. And this is not just a possibility. Historically speaking, the phenomenology owes its success to dozens of young students who philosophized together, thus creating one of the most remarkable sociological phenomena as far as scientific communities in the twentieth-century go (Sobota, 2017, part I). The history of the phenomenological movement shows that this co-philosophizing far exceeded what was (and still is) meant by university life. Phenomenological movement was regarded almost as a kind of "sect", in which there occurred many an ecstasy, mystical experiences and conversions. On the basis of this community-related nature of phenomenology, Herbert Spiegelberg tried in the seventies, as in the heyday of Grotowski's theater, "doing phenomenology" in small communities of students (Spiegelberg, 1975).

And so it is with the theatrical activities by Grotowski. It is known that the theater is a collective space and action. Nevertheless, Grotowski's theater far exceeded what was back then considered as theater. It was commonly believed that theater is a place of work (for actors) and place of entertainment (for the audience). By contrast - as Peter Brook says - Grotowski made theater a sacred place. Also Grotowski's theater - as before in the case of the Polish inter-war "Reduta" (Osterwa, 1991; Osiński, 2004) - was labeled as a sort of sect. Grotowski compared his theater with community and family. The adopted discipline and organization of work during rehearsals and performances are already legendary. The understanding of theater as community certainly corresponded with the atmosphere of socialist Poland, in which the emphasis was put on the social impact of any activity, including the art.

\section{Via negativa}

Truth is located in the phenomenon. This does not mean that it is enough to reach for it in order to have it. It takes long and tedious preparations. Oftentimes, when the question is posed on what exactly phenomenology is, the answer is that it is a method (Heidegger, 1987, p. 50). Methodical nature of phenomenology is undoubtedly linked with its social character. Methodical procedure ensures the reproducibility and efficiency - no matter who uses it. The method is supposed to pinpoint the truth in the phenomenon. You have to separate the wheat from the chaff. What lies hidden in the dark should be brought into the light. In the already mentioned phenomenological 
manifesto of 1911 (Philosophie als strenge Wissenschaft), Husserl defined the method of the new philosophical science as the one independent of any other methods or techniques. To see things as such without any prior assumptions you need to remove all the screens which had blurred the essence of things in the course of the history. Being free of assumptions is a way towards the truth. In Ideas I the free choice to reach the things as such is supported by the method of reduction and the principle of all principles (Husserl, 1976, $\S \S 31-32,24)$. Consecutive reductions lead to an unimpaired insight into the pure essence. What counts is only the diligent work on the phenomena. Bitte Sie Kleingeld - Husserl used to say to anyone who began to preach some great but not sanctioned ideas. This ethic of work focused on details brought phenomenology both a lot of supporters and opponents.

A similar methodical procedure can be found in Grotowski's theater. The answer to the question "What is the theater?" was pursued by Grotowski by the method of elimination and reduction (via negativa). The essence of theater manifests itself in the pure action of the actor towards the audience. The reduction should be conducted by one's entire self. It is not about the implementation of any previous theoretical assumptions into the theater, but the point is that the theatrical action should reveal the truth about itself. As in Husserl's philosophy, the path to this truth unfolds gradually. It is not enough to put a man in the middle of the stage, to deal with the truth. Grotowski discovered a whole bunch of the most diverse schemes of action, all sorts of clichés that man assumes while growing up and living within a given culture. It is all about the various activities related to the practice of everyday life. In addition to the various pragmatic schemes, human activity is formed by a great number of instructions and worldviews. We do not act as free beings, but our actions are shrouded in a dark mist of patterns and habits. So, to get to the truth of action, which is an essence of the theatrical phenomenon, one needs to employ a negative method of identifying and eliminating all sorts of psychological, physical and spiritual barriers. This purpose is served by an actor's training. However, one must not fetishize it. Unveiling the truth does not take place by virtue of arming oneself with all sorts of techniques or tricks bur rather of disarming. It's about purity, nudity, honesty and openness of contact. The richness of the theater is its poverty. 


\section{Ecce homo!}

There is as much Being as there are Phenomena. And that in turn means at the same time: there is a Phenomena as long as there is appearing. The latter is just another label for intentionality. Just as appearing is always appearing of something to somebody, so is consciousness somebody's consciousness of something. A phenomenon appears from a certain perspective. Therefore, to reveal the truth in the phenomenon, you must realize its perspectivity: that it is always for someone. Thus, phenomenological investigations, focusing on the appearance of a phenomenon, opens up the domain of pure subjectivity as residuum which resisted the process of phenomenological reduction. Phenomenology begins from the moment of shifting one's attention from the world into consciousness. After all, it took a lot of studies and the work of many researchers to realize that the consciousness is by no means the whole, but only a part of a wider horizon of transcendental grounding. Under the cover of consciousness, what manifested itself was the inexhaustible world of life, of being-in-the-world, intersubjectivity and bodily experiences. It is in these areas that the sought-for essence of the phenomena seems to lie. Especially bodiliness is this aspect of human experience of the world that is of particular interest to phenomenologists.

The poor theater begins with the reduction of everything that is not a theater. To get to the core of theater, one needs to reject - or rather, temporarily forget - everything over and above what is "theatrical". In the empty space there is a man called the actor who is in front of another person, called a spectator. In the course of the performance the spectator becomes a witness. The theater is a meeting of a man with another man face to face. "It's me" - says the actor - "for you, instead of you, to you". Suspension of everything that is not a theater, reveals a man in his bodily being right here. In the course of the actor's working on his role - as Konstantin Stanislavsky said - "actor's work on himself”' (Stanislavski, 1988), it transpires, however, that this carnal concrete man can reveal himself in his whole truth only if what got opened in him are the paths pointing at what is over and above not only his particular physical embodiment but also what is beyond here and now, and even beyond that distinct man. The point is to get through the body to humanity, divinity and nature. The actor, like an icon, becomes a window of eternity. It is on its horizon that he experiences self-revelation. 


\section{Work on Yourself}

The unveiling of the domain of the pure, deep consciousness begins phenomenological work of reflection (Besinnung). It is closely related to acts of memory and imagination. The phenomenological work involves describing, analyzing, distinguishing and illuminating phenomena, etc. The investigation reveals the layer of constitution of sense, combinations of motivations, and a stack of syntheses. Consciousness appears as an inexhaustible field of the transcendental activity which has its own history. Husserl speaks of the phenomenological knowledge as a repetition of this history in the new acts of phenomenological knowledge (Husserl, 1997, Introduction). But in order to enter and stay on this path of phenomenological research it is not enough to meet specific instructions such as "I ask you now to carry out reduction and suspend the thesis about the existence of the world" or "make now eidetic variation". Of course, this kind of technical instructions constitute the methodicalness of phenomenology and protect it against a temptation of "sudden revelations" and "exultation of spirit". The phenomenological reduction is alien to the natural setting and therefore it requires an explicit instruction how to carry it out. However, the phenomenological investigation is not a mere application of a particular technique while working on the phenomena, but it grows out of the adoption of the specific attitude that is out of the turn and the transformation of a philosophizing person. Especially in Scheler's thought, there appears the call to assume a proper ethical attitude, to asceticism, to awaken in oneself sources of love, because only love and true passion can guide cognition. Scheler writes about the act of the whole personality as a moral condition of philosophical cognition (Scheler, 1987, p. 250). It is always the whole man that philosophizes. Scheler, and then Fink, compares philosophical knowledge with Plato's allegory of exiting the cave. They accept this allegory, but - which will be equally important for Grotowski - they reject Plato's metaphysical and theological conviction that philosophizing is a fight with the body and an "exercise in dying". From the phenomenological perspective Plato's deprecating of sensuality and body is a big mistake. Therefore - according to Scheler - what should be retained from Platonic definition of philosophy are only two things: philosophy needs a "comprehensive act of the essence of a person" and that this act is founded on love, which allows man to participate in the essence of all possible things (Scheler, 1987, p. 250). Scheler speaks of "participation of a finite core of 
the human person in what is essential". In the case of philosophy the last one is the noesis, but in the case of the other spiritual activities it may be something else. He also mentions the distinction, which is also present in Nietzsche and which became the point of departure for the comparison of Grotowski's philosophy and phenomenology, namely the difference between what is Apollonian and Dionysian. In any case, philosophy can thrive only on properly prepared personal ground. What is necessary is love, humility and self-control (Scheler, 1987, p. 286). Only on the prepared ground there may take place the participation in what is essential, and consequently the full responsibility, about which Husserl wrote.

It is not difficult to find the same ethical motives in Grotowski's thought. The compliance with the quasi-monastic ethic of work and ethics were the starting point of Grotowski's theatrical work. Grotowski uses similar terms to Scheler's: humility, devotion, solidarity, understanding. The poor theater focuses on a man in his bodily concreteness. The primary phenomenon is therefore the human body and its performative manifestations. The truth about man and his world, and his gods, lies in his corporeality. Just as phenomenology, a human body is what goes beyond the distinction into biology and culture. The theatrical body also transcends the distinction between body which is seen from the inside (Leib) and body which is given from the outside (Körper). It is rather a body situated between interiority of experience and exteriority of expression.

In it exactly in this chasm that the actor's work on himself takes place. The starting point of Grotowski's cooperation with the actor is an indication of his "natural" everyday attitude. Its specificity stems from the cultural assimilation of Platonic-Cartesian division of man into the human body and soul. In this model, the body is a dark material corpus, and consciousness is lightness and openness. The corpus is principally unavailable to the said light. The consciousness illuminates it only partially and superficially. Hence the conflict and sharp internal division of man. Man of European civilization lives in a split personality. It creates a schizophrenic culture too. When the actor begins to work on himself and his body, his primary task is the destruction of this division. It consists of re-integration by rejecting the blockades and restrictions, opening the channels of flow of energy between body and soul, their fusion. The work on the body, practiced as the hard physical training, has to attain such a depressurization of the body, or such a "ventilation" thereof that the light of consciousness could reach 
as far as possible and brighten up its initially closed and dark regions. This successful act of "scanning" the body, in which the body becomes a reflector of soul, Grotowski called the total act. Only now the body becomes a pure phenomenon, a living manifestation of the truth, a luminous body-spirit. Before this happens, however, it takes a long-term physical and mental training. The work of an actor on himself is associated with reconstructing some rudimentary experience from the past in which he immerses his role. The aim is not to re-awaken some old feelings or emotions, but to recapture those impulses that lay at the basis of a particular action as materializing in a given situation. Thus, by looking backwards an actor transcends his individual existence, he becomes a mirror that reflects the history of man, nature and the gods. And thus he encounters others and the Other.

\section{The Total Act}

Scheler mentions the climax of the phenomenological cognition, the total act of participation of the human person in the essence. To know the essence - says Scheler - one must become similar to it, one must become oneself an essential and eternal being. If a correlate of infinite world of essences is an idea of infinite personality, i.e. God, then a phenomenologizing subject, aspiring to participate in this infinite world of essences, must transcend his human nature and enter the path of self-divination (Scheler, 1987, p. 281). This is, of course, nothing permanent. This rise of cognition is only temporary and very rare indeed. Plato talked about jumping out of the sea in the same manner as the flying fish does.

In the history of the twentieth century, the phenomenology of body has come a long way from the understanding of the body as corpus (Körper) through corporeality given in inner experience (Leib) right into the notion of the body defined as intelligible, spiritual glorious and sort of extraterrestrial (Henry, 2012). One could claim that in Grotowski's theater all of these dimensions of corporeality matter although the most important one of them is this form of body which is manifested in the total act.

In Grotowski's theater the total act is the culmination of the theatrical action. It is an act of confession, redemption, self-giving and love. Grotowski compares this act with Plato's allegory of the cave, or with figures depicted by El Greco, with self-immolation and finally with the sacrifice of 
Christ. In professional literature, one encounters the claim that in Grotowski's performances there is always one hero: Christ. In the total act, the subject is not so much the one who reveals the phenomena, but the one who becomes a phenomenon itself. One could, following Emmanuel Levinas, define this phenomenon as the face, or - as Jean Luc-Marion did - as a "saturated phenomenon".

\section{Flesh was made word}

When Husserl recommends doing away with empty words and turning attention back to things, he does not demand, of course, the rejection of any talk whatsoever, but only of this kind thereof that is not anchored in things as seen. The possibility of speaking and expressing one's thoughts in a language is the main subject of Logic Investigation and also one of the main problems of phenomenology. Husserl's effort to find the right word to describe things as seen constitutes a poignant testimony to and a symbol of a fundamental "aporia", which lies at the very basis of this philosophy. It looks as if the word by its very nature was sort of irreconcilable with seeing, as if the gap between word and insight was unbridgeable. Therefore, from the very beginning of the phenomenological movement, Husserl and his students were looking for such a kind of philosophical language that can minimize this discrepancy. It was about the utterances which do not objectivize. Hence what seemed to be of great interest to them were also other experiences and their respective expressions than those strictly connected with logic or epistemology (Sobota, 2018, p. 710).

In traditional theater the most important thing was a word. The theater was subordinated to a play. The function of the actor involved finding the most convincing way of presenting the script and following a director's commands. The actor spoke his part standing in front of the scene and illustrating it additionally with "theatrical" gestures. The actor was struggling to fill words with emotions. Hence, the word had a chance to grab the attention of a spectator and thus to engage him in a spectacle.

In Grotowski's theater the word is only one of the elements of action, but a very important one. What Grotowski decided to stage were various texts, usually classic dramatic works. They normally depicted some archetypal situation of the human race. But the word as such is empty. Hence the most important thing was that the actor once again immerses the meaning 
of words in the sources of his own corporeality. The point was to find such personal experience that would correspond to the meaning of a given utterance. However, not in order to - as in traditional theater - fill the words with emotions. For emotions - according to Grotowski's psychology - are beyond our control and appear when they want to do so and not when we want them to appear. What we have a control over are physical actions. And it is the said physical actions that the actor should fill the words of a staged text with. The word as a sign and expression of something inside should appear as the last stage of a physical activity. As in Levinas, what has been Said (le dit) is preceded by Saying (le dire) (Levinas, 2000, pp. 14-19). The physical action constitutes such Speaking, which allows the word to be spread in the world. The embodied word crowns the process of self-revelation.

\section{Other}

In the history of the phenomenological movement, the issues related to bodiliness were considered in parallel with the problems of intersubjectivity. The possibility and necessity of this combination was presented by Husserl in his Cartesian Meditations. In other phenomenologists, such as Sartre or Levinas, the encounter of man with his corporeality takes a more dramatic course. And Grotowski's theater is very much alike.

Theater has always been a place for people meeting. In Grotowski's theater, this moment is elevated to the rank of one of the most important moments of an entire performance. In the rich theater, there dominates this type of encounter with the Other which Sartre described. The spectator objectifies the actor, the former reduces the latter to the former's object of cognition. As opposed to the rich theater, in the poor theater the interbodily relation is quite different and is similar to the way it is represented by Levinas rather than by Sartre (Levinas, 1998, part III; Sartre, 2007, part III, chapt. IV). In the poor theater, interbodily relations extend in many different directions. These encompass the following relationships: actor-actor, actor-safe partner, actor-witness, actor-director, actor-world of things. At the end of the sixties Grotowski postulates leaving the theater. He believed that the theater is too limited a space for interbodily relations to be instantiated there. The point was that the total act should be exemplified in the daily life: in the relation of brotherhood with others and with the Nature. What matters is an encounter, a Holiday (Grotowski, 2012, p. 510). 


\section{Conclusions \\ In Quest of Unity}

The comparison of Grotowski's philosophy of theater and main ideas of phenomenology leads to a few conclusions.

Firstly, due to the comparison of phenomenology with Grotowski's philosophy of theater, each party can be considered from a new angle and thus becomes illuminated and more profoundly understood. Thanks to the shift of some discoveries in the realm of phenomenology into the field of theater, the latter gains the necessary tools by virtue of which it may express its otherwise dark intuitions. At the same time the discoveries of phenomenology are verified and subjected to concretization. So, each of them is sort of investigated and elucidated.

Secondly, the comparison reveals also, however, that Grotowski's work is not only a phenomenon parallel to phenomenology, but it is a successful suggestion of transferring certain discoveries in the field of phenomenology into daily practice. Thus it constitutes a specific historical answer to fundamental needs and yearnings that were harbored by the representatives of the phenomenological movement from the time of its inception. The call by Natalie Depraz and other representatives of the movement to "do phenomenology" and the confrontation of phenomenology with other areas of experience assume quite a real shape here. In fact, Grotowski anticipated many solutions that have emerged in recent phenomenology. Grotowski himself - not counting the work of Sartre - did not know phenomenology. He subsumed his philosophy under a tradition which was quite alien to phenomenology.

Thirdly, this juxtaposition of phenomenology with Grotowski's work suggests that the analogous structures of both of them reflect some underlying pre-structure of incarnated-spiritual life as such. It occurs as a base structure not only in phenomenology or Grotowski's theater, but wherever we encounter the workings of incarnated spirit. This observation can be a point of departure for further research: treating phenomenology and Grotowski's theater as our paradigm, we can describe elementary constituents and internal relations of any incarnated-spiritual life. 


\section{References}

Arendt, H. (1981). The Life of the Mind. San Diego-New York-London: A Harvest Book \& Harcourt Inc.

Artaud, A. Teatr i jego sobowtóry. Trans. J. Błoński. Publisher Czuły Barbarzyńca, without a place or date.

Bacon, F. (1905). Works. Ed. J.M. Robertson. London: Routledge.

Brook, P. (2007). Teatr jest tylko forma. O Jerzym Grotowskim. The collection of essays: G. Banu, G. Ziółkowski. Wrocław: Instytut im. Jerzego Grotowskiego.

Degler, J., Ziółkowski, G. (ed.) (2016). Misterium grozy i urzeczenia. Przedstawienia Jerzego Grotowskiego i Teatru Laboratorium. Wrocław: Instytut im. Jerzego Grotowskiego.

Depraz, N. (2010). Zrozumiećfenomenologię. Praktyka konkretu. Trans. A. Czarnacka. Warszawa: Oficyna Naukowa.

Gadamer, H.-G. (2004). Truth and Method. Trans. J. Weinsheimer, D.G. Marshall. London-New York: Continuum.

Gajda, J. (1996). Pitagorejczycy. Warszawa: Wiedza Powszechna.

Grotowski, J. (1984). Towards a Poor Theater. London: Methuen.

Grotowski, J. (2012). Teksty zebrane [Collected texts]. Warszawa: Instytut im. Jerzego Grotowskiego, Instytut Teatralny im. Z. Raszewskiego, Wydawnictwo Krytyki Politycznej.

Heidegger, M. (1987). Being and Time. Trans. J. Macquarrie, E. Robinson. Oxford: Basil Blackwell.

Heidegger, M. (1997). Drogi lasu. Trans. by a team. Warszawa: Fundacja Aletheia.

Henry, M. (2007). O fenomenologii. Trans. M. Drwięga. Warszawa: Institute of Philosophy and Sociology in Polish Academy of Sciences.

Henry, M. (2012). Wcielenie. Filozofia ciała. Trans. M. Frankiewicz, D. Adamski. Kraków: Homini.

Husserl E. (1976). Husserliana. Vol. III: Ideen zu einer reinen Phänomenologie und phänomenologischen Philosophie. Erstes Buch. Ed. K. Schuhmann. Den Haag: Martinus Nijhoff. 
Husserl E. (1980). Husserliana. Vol. XXIII. Phantasie, Bildbewusstsein, Erinnerung. Zur Phänomenologie der anschaulichen Vergegenswärtigungen. Texte aus dem Nachlass (1898-1925). Ed. E. Marbach. Den Haag: Martinus Nijhoff.

Husserl, E. (1997). Erfahrung und Urteil: Untersuchungen zur Genealogie der Logik. Hamburg: Felix Meiner Verlag.

Husserl E. (1910-1911). Philosophie als strenge Wissenschaft. Logos. Internationale Zeitschrift für Philosophie der Kultur, 1 (3), 289-341.

Johnston, D. (2017). Theater and Phenomenology. Manual Philosophy. London: Palgrave Macmillian.

Diogenes Laertius (2013). Lives of Eminent Philosophers. Ed. T. Dorandi. Cambridge: Cambridge University Press.

Levinas, E. (1998). Całość i nieskończoność. Esej o zewnętrzności. Trans. M. Kowalska. Warszawa: Wydawnictwo Naukowe PWN.

Levinas, E. (2000). Inaczej niż być lub ponad istota. Trans. P. Mrówczyński. Warszawa: Fundacja Aletheia.

Nietzsche, F. (1905). The Complete Works. Vol. I: The Birth of Tragedy or Hellenism and Pessimism. Trans. A. Haussmann. London.

Nietzsche, F. (1905-1906). Z genealogii moralności. Pismo polemiczne. Trans. L. Staff. Warszawa: Nakład Jakóba Mortkowicza.

Osiński, Z. (1972). Teatr Dionizosa. Romantyzm w polskim teatrze współczesnym. Kraków: Wydawnictwo Literackie.

Osiński, Z. (1980). Grotowski i jego Laboratorium. Warszawa: PIW.

Osiński, Z. (2004). Pamięć Reduty. Osterwa, Limanowski, Grotowski. Gdańsk: słowo/obraz terytoria.

Osiński, Z. (2009). Jerzy Grotowski. Źródła, inspiracje, konteksty. Vol. I. Gdańsk: słowo/obraz terytoria.

Osterwa, J. (1991). Reduta i teatr. Artykuły, wywiady, wspomnienia. 1914-1947. Wrocław: Wydawnictwo „Wiedza o Kulturze” Fundacji dla Uniwersytetu Wrocławskiego.

Płotka, W. (2015). Studia z fenomenologii poznania. Transcendentalna filozofia Edmunda Husserla a problem wiedzy. Gdańsk: Wydawnictwo Uniwersytetu Gdańskiego. 
Salata, K. (2012). The Unwritten Grotowski: Theory and Practice of the Encounter. Routledge Advances in Theater \& Performance Studies.

Sartre, J.P. (2007). Byt i nicość. Zarys ontologii fenomenologicznej. Trans. J. Kiełbasa. Kraków: Zielona Sowa.

Schapp, W. (1976). Beiträge zur Phänomenologie der Wahrnehmung. Wiesbaden: B. Heymann Verlag.

Scheler, M. (1987). Pisma z antropologii filozoficznej i teorii wiedzy. Trans. S. Czerniak, A. Węgrzecki. Warszawa: PWN.

States, B.O. (1985). Great Reckonings in Little Rooms. Berkeley-Los AngelesLondon: California University Press.

Sobota, D.R. (2017). Narodziny fenomenologii z ducha pytania. Johannes Daubert i fenomenologiczny rozruch. Warszawa: Instytut Filozofii i Socjologii PAN.

Spiegelberg, H. (1960). The Phenomenological Movement. A Historical Introduction. Dordrecht: Springer Science+Business Media.

Spiegelberg, H. (1975). Doing Phenomenology. Essays on and in Phenomenology. The Hague: Martinus Nijhoff.

Stanislavski, K. (1988). An Actor Prepares. London: Methuen.

Waldenfels, B. (1983). Phänomenologie in Frankreich. Frankfurt am Main: Suhrkamp Verlag.

Waldenfels, B. (2002). Topografie obcego. Trans. J. Sidorek. Warszawa: Oficyna Naukowa. 


\begin{abstract}
In his phenomenological manifesto (1911), Edmund Husserl presents the famous motto, which should be realized by the new philosophy: "Weg mit den hohlen Wortanalysen. Die Sachen selbst wir müssen befragen. [...] Ganz trefflich! Aber was sind denn die Sachen [...]?" Consequently, the history of phenomenology is presented as the sum of the efforts to reach the deeper level and more fundamental areas of the original "Sachen". Husserl's discovery of the domain of pure consciousness was only the beginning of a long way leading to more original areas, such as life, existence, body, intersubjectivity, historicity, humanity, etc. With this journey towards deeper fields of sense-constitution, the meaning of the phenomenological method was changed. Phenomenology cannot be a simple work of a lonely soul looking for self-transparency in the field of its own consciousness, but it must be a kind of action, a deed, an existential transformation, and an increase of experience.

In my paper I would like to explore structural similarities between phenomenology and the theatrical practice of Polish theater reformer Jerzy Grotowski (1933-1999). Although he was neither a phenomenologist, nor a philosopher, in his notes on the human performance, collected and entitled Toward a Poor Theater, he presents a method of creating and conceiving of theatrical action which is marked with motivations, structure and process similar to what representatives of the phenomenological movement actually realize. In other words, between the works by Grotowski and representatives of the phenomenological movement, there are many analogies that the present paper purports to uncover and systematically illuminate.
\end{abstract}

